\title{
SISTEM PENDUKUNG KEPUTUSAN KARYAWAN TERBAIK DENGAN METODE SAW DI PT FINS CATERING
}

\author{
Wahyu Hadiwiyono $^{1}$, Ika Mei Lina ${ }^{2}$ \\ ${ }^{1,2}$ Program Studi Teknik Informatika, Fakultas Teknik dan Ilmu Komputer, \\ Universitas Indraprasta PGRI \\ Jalan Raya Tengah No 80, Kelurahan Gedong, Pasar Rebo, Jakarta Timur \\ whadi589@gmail.com ${ }^{1}, \underline{\text { ikameilina.24@gmail.com }}{ }^{2}$
}

\begin{abstract}
Abstrak
Tujuan penelitian adalah untuk membuat sebuah sistem pendukung keputusan dimana bertujuan untuk membantu PT Fins Catering dalam menerapkan sistem pendukung keputusan yang terkomputerisasi dan terhubung langsung dengan database sehingga dapat dengan mudah mengantisipasi permasalahan duplikasi data serta efisien dan efektif. Metode penelitian yang digunakan dalam penelitian sistem pendukung keputusan pemilihan karyawan terbaik di PT Fins Catering adalah observasi, metode wawancara untuk mendapatkan data yang lengkap. Setelah itu hasil penelitian sistem pendukung keputusan ini adalah menghasilkan suatu sistem pendukung keputusan pemilihan karyawan terbaik yang bisa memberikan layanan dengan baik kepada PT Fins Catering meliputi kemudahan dan keakuratan dalam melakukan perhitungan pemilihan karyawan terbaik, penyusunan laporan-laporan, serta pencarian data-data.
\end{abstract}

Kata Kunci : Perancangan, Sistem Pendukung Keputusan, Karyawan, Java

\begin{abstract}
The purpose of this research is to create a decision support system which aims to assist PT Fins Catering in implementing a computerized decision support system that is directly connected to the database so that it can easily anticipate data duplication problems as well as efficiently and effectively. The research method used in the research of the best employee selection decision support system at PT Fins Catering is observation, interview methods to obtain complete data. After that, the results of this decision support system research are to produce a decision support system for selecting the best employees who can provide good services to PT Fins Catering including ease and accuracy in calculating the best employee selection, compiling reports, and searching for data.
\end{abstract}

Keyword : Planning, Decision Support System, Employee, Java

\section{PENDAHULUAN}

Karyawan merupakan sumber daya manusia terkadang disebut dengan aset perusahaan. Keberhasilan karyawan dalam mengerjakan tugasnya dengan baik dapat meningkatkan produktivitas perusahaan, maka perusahaan melakukan penilaian untuk menentukan karyawan terbaik. Dalam pemilihan karyawan terbaik, perusahaan akan menilai atau mengevaluasi terhadap kinerja karyawan dengan jangka waktu yang telah ditentukan. PT. Fins Catering belum pernah menerapkan sistem pengambilan keputusan karyawan terbaik secara spesifik. Dalam melakukan pemilihan karyawan terbaik untuk memicu semangat karyawan dalam meningkatkan kualitas dan kinerjanya. Pemilihan karyawan terbaik dilakukan secara periode. Kendala yang dialami PT Fins Catering tidak transparan dalam melakukan pemilihan karyawan terbaik, dan belum adanya sistem yang terkomputerisasi untuk pemilihan karyawan terbaik. Penelitian ini menggunakan metode Simple Additive Weighting yang biasa dikenal dengan metode penjumlahan terbobot. Dengan adanya sistem pendukung keputusan pemilihan karyawan terbaik ini mampu menerapkan penilaian terhadap karyawan secara spesifik dan terdata. Kemudian pemilihan karyawan terbaik dengan sistem yang transparan, serta membuat sistem pendukung keputusan yang dapat membuat keputusan yang akurat dan efektif sehingga menghemat waktu dan tenaga. Manfaat dari hasil penelitian ini untuk membantu Manager Operasional dalam mengelolah data karyawan menjadi lebih efektif dan hemat waktu dalam menentukan karyawan terbaik, selain itu mampu 
mengoptimalkan pemilihan karyawan terbaik dengan indikator kriteria yaitu loyalitas, kehadiran, kedisiplinan, perilaku, kerjasama sehingga penilaian lebih objektif.

\section{PENELITIAN RELEVAN}

Untuk membuat dasar penelitian maka penulis mencari penelitian yang berhubungan dengan topik yang penulis bahas yaitu mengenai Sistem Pendukung Keputusan dengan Metode Simple Additive Weighting (SAW). Penelitian yang pertama dilakukan oleh (Ahmad \& Kurniawan, 2020) dengan judul Sistem Pendukung Keputusan Pemilihan Karyawan Terbaik Menggunakan Simple Additive Weighting. Penelitian ini bertujuan untuk dapat membantu pimpinan perusahaan dalam membuat keputusan pemilihan karyawan terbaik dan untuk mengukur kinerja karyawan yang jauh lebih mudah, cepat dan objektif. Hasil penelitian ini membantu pimpinan perusahaan dalam membuat keputusan pemilihan karyawan terbaik dan untuk mengukur kinerja karyawan yang lebih mudah, cepat dan objektif. Penelitian yang kedua dilakukan oleh (Pareda et al., 2019) dengan judul Sistem Pendukung Keputusan Pemilihan Karyawan Teladan di PT Aneka Tambang (ANTAM) Tbk Unit Bisnis Pertambangan Buli Menggunakan Metode Simple Additive Weight (SAW). Penelitian ini bertujuan untuk merancang sebuah sistem pendukung keputusan dalam pemilihan karyawan teladan di PT ANTAM Tbk. Hasil penelitian ini membantu manajemen dalam memecahkan masalah yang kompleks dengan integrasi berbagai sumber informasi.

\section{METODE PENELITIAN}

Metode penelitian yang digunakan adalah Research and Development. Metode Research and Development merupakan suatu proses atau langkah-langkah untuk mengembangkan suatu produk baru untuk menyempurnakan produk yang telah ada. Berikut metode pengumpulan data penelitian ini sebagai berikut:

1. Observasi

Observasi dilakukan pada pihak yang berkaitan untuk mendapatkan data secara umum dengan melihat langsung. Dalam hal ini penelitian melihat langsung proses penilaian karyawan pada PT Fins Catering.

2. Wawancara

Dengan melakukan pengumpulan data dengan mengadakan tanya jawab dengan manajer operasional secara langsung yang berakaitan dengan topik yang akan dilakukan penelitian. Proses ini perlu dilakukan secara langsung, untuk mendapat data yang benar-benar objektif dan dapat dipertanggungjawabkan.

3. Studi Pustaka

Dengan membaca dan mempelajari dari buku dan artikel maupun informasi lainnya yang berkaitan dengan masalah yang diteliti.

\section{HASIL DAN PEMBAHASAN}

Simple Additive Weighting adalah salah satu metode untuk pengambilan keputusan multi-atribut. Ini digunakan untuk menentukan alternatif terbaik dari banyaknya alternatif (Ahmad \& Kurniawan, 2020). Dan Simple Additive Weighting sering juga dikenal dengan istilah metode penjumlahan terbobot. Konsep dasar metode Simple Additive Weighting adalah mencari penjumlahan terbobot dari rating kinerja pada setiap alternatif pada semua atribut. Metode Simple Additive Weighting membutuhkan proses normalisasi matriks keputusan $(\mathrm{X})$ ke suatu skala yang dapat diperbandingkan dengan semua rating alternatif yang ada. Metode SAW ini mengharuskan pembuat keputusan menentukan bobot setiap atribut. Skor total untuk alternatif diperoleh dengan menjumlahkan seluruh hasil perkalian antara rating (yang dapat dibandingkan lintas atribut) dan bobot tiap atribut. Rating tiap atribut haruslah bebas dimensi dalam arti telah melewati proses normalisasi matriks sebelumnya. 
Berikut adalah contoh pehitungan metode SAW:

Tabel 1. Alternatif

\begin{tabular}{|l|l|}
\hline Var & \multicolumn{1}{|c|}{ Nama Alternatif } \\
\hline A1 & Abdurahman \\
\hline A2 & Annisa Putri \\
\hline A3 & Bima Putra \\
\hline A4 & Mochammad Ikhsan \\
\hline A5 & Shifa Maulana \\
\hline
\end{tabular}

Tabel 2. Kriteria

\begin{tabular}{|l|l|l|}
\hline Var & \multicolumn{1}{|c|}{ Nama Kriteria } & \multicolumn{1}{|c|}{ Benefit/Cost } \\
\hline C1 & Loyalitas & Benefit \\
\hline C2 & Kehadiran & Benefit \\
\hline C3 & Kedisiplinan & Benefit \\
\hline C4 & Perilaku & Benefit \\
\hline C5 & Kinerja & Benefit \\
\hline
\end{tabular}

Tabel 3. Bobot Kriteria

\begin{tabular}{|l|l|c|}
\hline Var & \multicolumn{1}{|c|}{ Nama Kriteria } & Nilai Bobot \\
\hline C1 & Loyalitas & 30 \\
\hline C2 & Kehadiran & 20 \\
\hline C3 & Kedisiplinan & 20 \\
\hline C4 & Perilaku & 15 \\
\hline C5 & Kinerja & 15 \\
\hline
\end{tabular}

Tabel 4. Bobot Kriteria

\begin{tabular}{|l|l|c|}
\hline Var & \multicolumn{1}{|c|}{ Bobot Kriteria } & Nilai Bobot \\
\hline C1 & Loyalitas & 30 \\
\hline C2 & Kehadiran & 20 \\
\hline C3 & Kedisiplinan & 20 \\
\hline C4 & Perilaku & 15 \\
\hline C5 & Kinerja & 15 \\
\hline
\end{tabular}

Tabel 5. Tabel Matriks Nilai Alternatif pada Setiap Kriteria

\begin{tabular}{|l|l|l|l|l|l|}
\hline & C1 & C2 & C3 & C4 & C5 \\
\hline A1 & 80 & 70 & 80 & 70 & 80 \\
\hline A2 & 60 & 80 & 50 & 85 & 50 \\
\hline $\mathbf{A 3}$ & 90 & 85 & 80 & 75 & 65 \\
\hline $\mathbf{A 4}$ & 70 & 75 & 60 & 90 & 70 \\
\hline $\mathbf{A 5}$ & 80 & 90 & 70 & 85 & 80 \\
\hline
\end{tabular}

Setelah semua data sudah ada, maka dapat dilakukan proses normalisasi nilai kriteria. Berikut adalah rumus normalisasi nilai kriteria metode SAW:

$$
r_{i j}=\left\{\begin{array}{l}
\frac{x_{i j}}{\operatorname{Max}_{i} x_{i j}} \\
\frac{\operatorname{Min}_{i} x_{i j}}{x_{i j}}
\end{array}\right.
$$

1. Normalisasi nilai kriteria cost:

$$
r_{i j}=\frac{\operatorname{Min}_{i} x_{i j}}{x_{i j}}
$$

2. Normalisasi nilai kriteri benefit:

$$
r_{i j}=\frac{x_{i j}}{\operatorname{Max}_{i} x_{i j}}
$$

Setelah semua nilai kriteria telah dinormalisasi dengan rumus-rumus diatas, maka akan didapatkan matriks normalisasi nilai kriteria sebagai berikut: 
Tabel 6. Matriks Normalisasi Nilai Kriteria

\begin{tabular}{|c|c|c|c|c|c|}
\hline & C1 & C2 & C3 & C4 & C5 \\
\hline A1 & 0,888 & 0,777 & 1 & 0,777 & 1 \\
\hline A2 & 0,666 & 0,888 & 0,625 & 0,944 & 0,625 \\
\hline A3 & 1 & 0,944 & 1 & 0,833 & 0,812 \\
\hline A4 & 0,777 & 0,833 & 0,75 & 1 & 0,875 \\
\hline A5 & 0,888 & 1 & 0,875 & 0,944 & 1 \\
\hline
\end{tabular}

Setelah dilakukan proses normalisasi nilai kriteria dan telah didapatkannya data matriks normalisasi nilai kriteria, maka dapat dilakukan proses perankingan. Berikut adalah rumus perankingan metode SAW:

$$
V_{i}=\sum_{j=i}^{n} w_{j} r_{i j}
$$

Proses perankingan ini dilakukan dengan menjumlahkan nilai kriteria yang telah dinormalisasi dengan data nilai bobot yang telah ditentukan. Berikut adalah proses perhitungan perankingan metode SAW:

$$
\begin{aligned}
& V_{1}=(30 * 0,888)+(20 * 0,777)+(20 * 1)+(15 * 0,777)+(15 * 1)=88,835 \\
& V_{2}=(30 * 0,666)+(20 * 0,888)+(20 * 0,625)+(15 * 0,944)+(15 * 1)=79,4 \\
& V_{3}=(30 * 1)+(20 * 0,944)+(20 * 1)+(15 * 0,833)+(15 * 1)=96,375 \\
& V_{4}=(30 * 0,777)+(20 * 0,833)+(20 * 0,75)+(15 * 1)+(15 * 1)=84,97 \\
& V_{5}=(30 * 0,888)+(20 * 1)+(20 * 0,875)+(15 * 0,944)+(15 * 1)=93,3
\end{aligned}
$$

Setelah dilakukan proses peringkat, maka akan didapatkan hasil akhir yang merupakan alternatif terbaik. Berikut adalah hasil akhir perhitungan metode SAW:

Tabel 7. Peringkat Nilai Alternatif

\begin{tabular}{|l|l|c|c|}
\hline & \multicolumn{1}{|c|}{ Nama Alternatif } & Nilai Alternatif & Ranking \\
\hline V1 & Abdurahman & 88,835 & 3 \\
\hline V2 & Annisa Putri & 79,4 & 5 \\
\hline V3 & Bima Putra & $\mathbf{9 6 , 3 7 5}$ & $\mathbf{1}$ \\
\hline V4 & Mochammad Ikhsan & 84,97 & 4 \\
\hline V5 & Shifa Maulana & 93,3 & 2 \\
\hline
\end{tabular}

\section{Diagram Alir Data (DAD)}

Diagram Alir Data (DAD) atau Data Flow Diagram (DFD) merupakan gambaran suatu sistem yang telah ada atau sistem baru yang dikembangkan secara logika tanpa mempertimbangkan lingkungan fisik dimana data tersebut mengalir. Dengan adanya Data Flow Diagram (DFD), maka pemakai sistem yang kurang memahami di bidang komputer dapat mengerti sistem yang sedang berjalan (Muslihudin \& Oktafianto, 2016:48). Adapun Diagram Alir Data (DAD) sistem yang diusulkan dalam Diagram Konteks adalah sebagai berikut: 


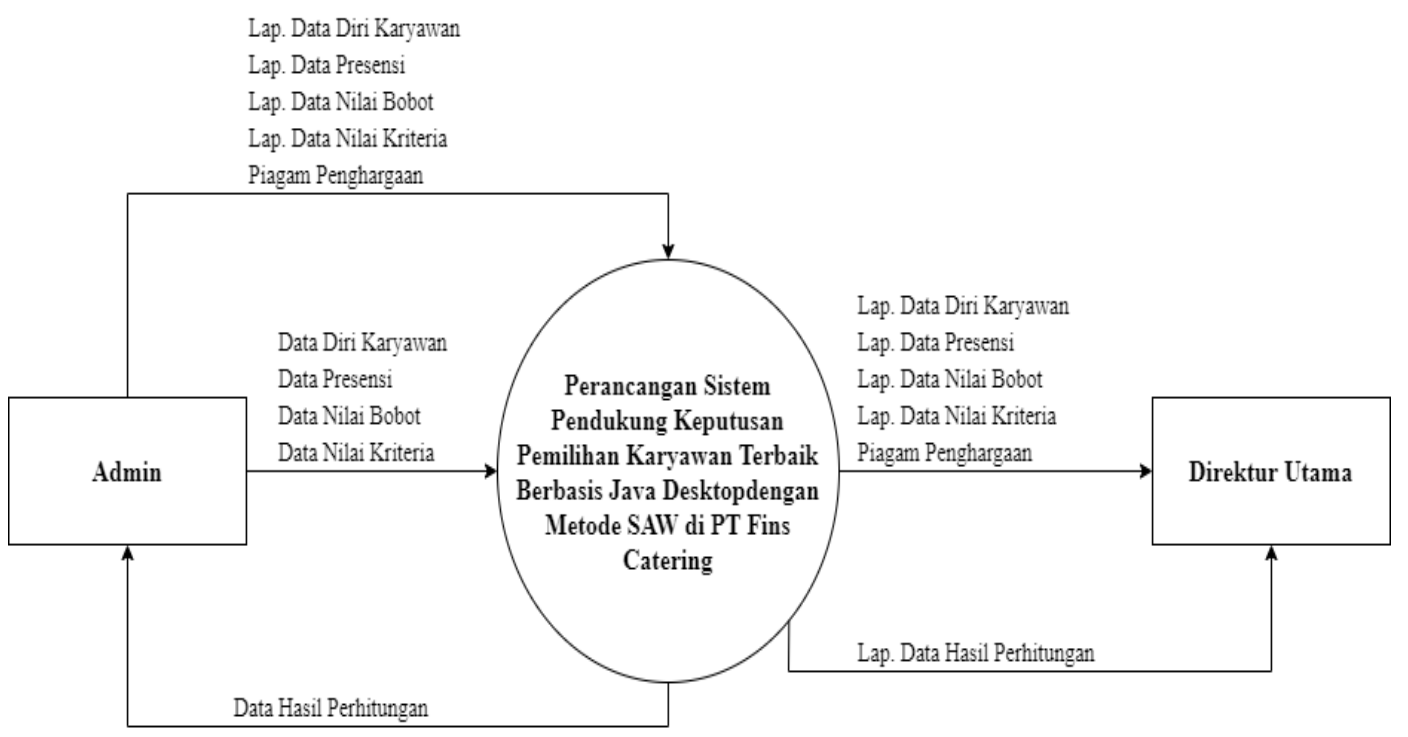

Gambar 1. Diagram Konteks Sistem yang Diusulkan

\section{Entity Relationship Diagram (ERD)}

Entity Relationship Diagram (ERD) merupakan suatu model untuk menjelaskan hubungan antar data dalam basis data berdasarkan objek-objek dasar data yang sering kita jumpai dalam aktifitas pengembangan sistem oleh sistem analitis. ERD merupakan gambaran grafis dari suatu model data yang menyertakan deskripsi detail dari seluruh entitas (entity), hubungan (relationship), dan batasan (constraint) untuk memenuhi kebutuhan sistem analis dalam menyelesaikan pengembangan sebuah sistem (Suprihatin, 2018:30-31). Berikut adalah gambar ERD sistem yang diusulkan:

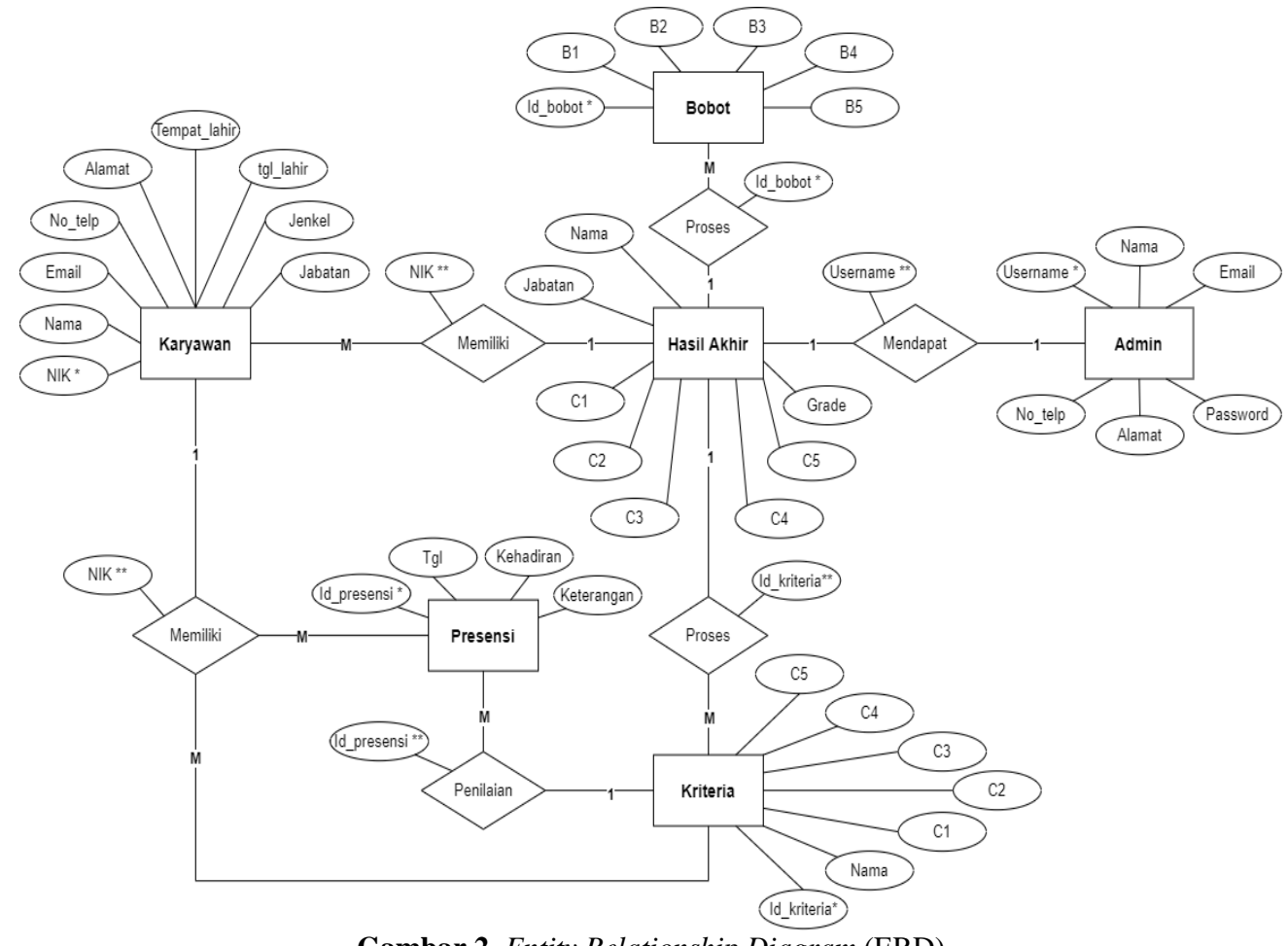

Dalam Perancangan Sistem Pendukung Keputusan Pemilihan Karyawan Terbaik di PT. Fins Catering, penulis menggunakan software NetBeans IDE dan MySQL dari XAMPP. Berikut adalah beberapa tampilan pada Perancangan Sistem Pendukung Keputusan Pemilihan Karyawan Terbaik di PT. Fins Catering: 


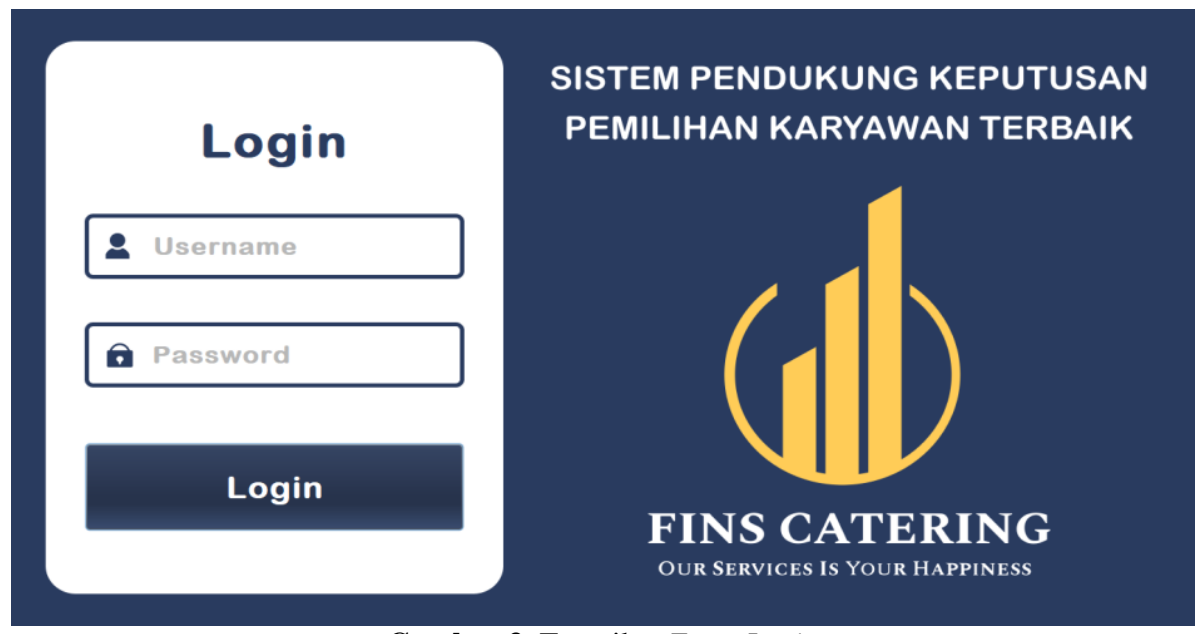

Gambar 3. Tampilan Form Login

Tampilan diatas merupakan tampilan dari form Login. Admin dapat memasukkan username dan password agar dapat mengakses aplikasi. Jika username dan password sesuai dengan data yang telah ada, maka admin akan masuk ke dalam tampilan Dasbor.

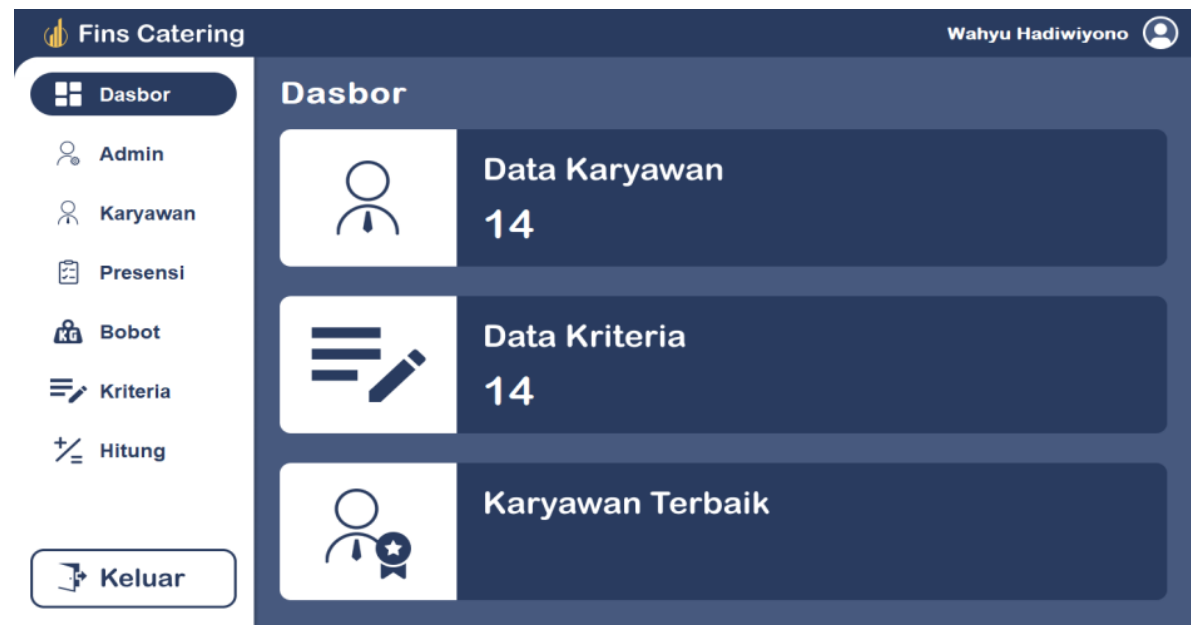

Gambar 4. Tampilan Form Dasbor

Tampilan diatas merupakan tampilan dari form Dasbor. Pada form Dasbor ini admin dapat kita dapat melihat informasi untuk mengetahui jumlah data karyawan, jumlah kriteria karyawan, karyawan terbaik. Karyawan terbaik akan muncul jika sudah melakukan hasil akhir perhitungan.

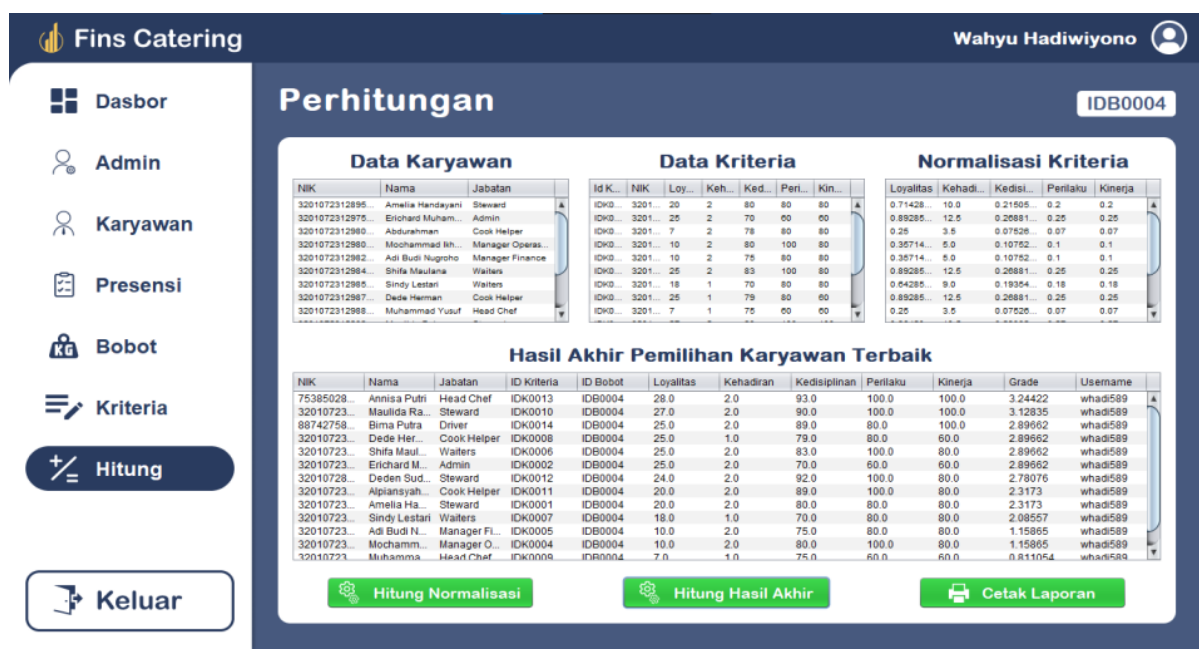

Gambar 5. Tampilan Form Perhitungan 
Tampilan diatas merupakan tampilan dari form Perhitungan. Disini admin dapat melakukan normalisasi nilai kriteria karyawan yang telah dimasukkan pada form Data Kriteria dan melakukan penentuan peringkat dengan mengkonversikan nilai normalisasi kriteria dengan nilai bobot kriteria yang telah dimasukkan pada form Data Bobot.

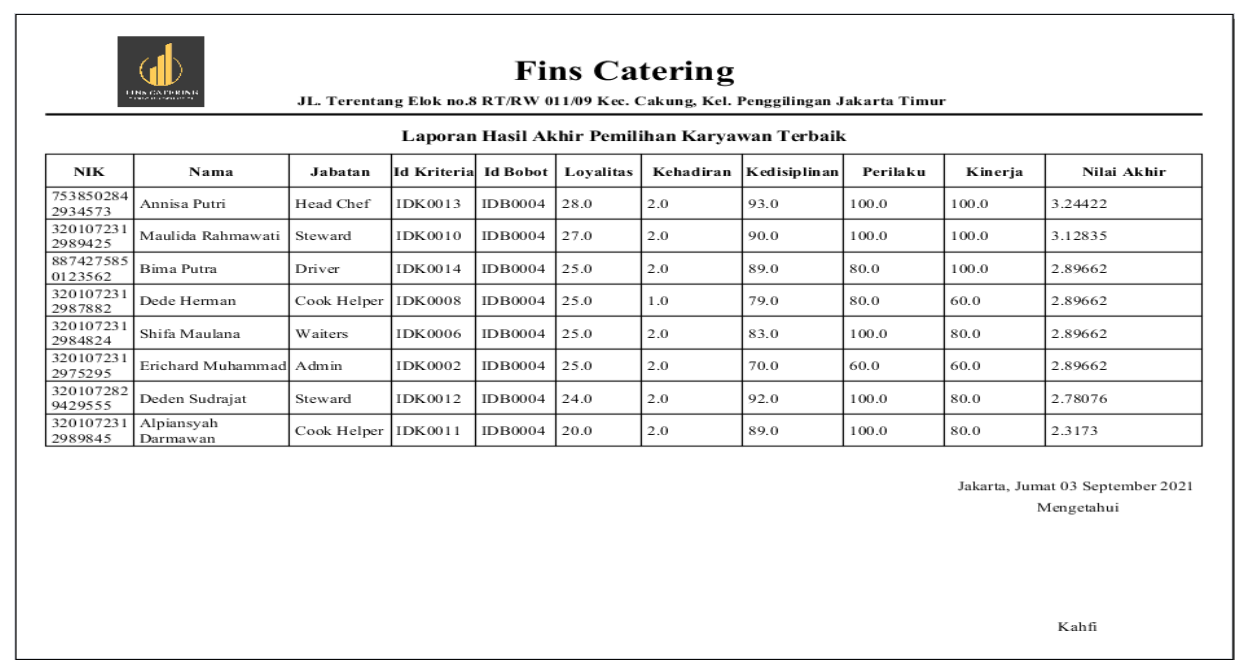

Gambar 7. Tampilan Keluaran Data Hasil Perhitungan

Tampilan diatas merupakan tampilan keluaran Laporan Data Hasil Perhitungan yang merupakan hasil akhir dari keseluruhan proses dari aplikasi Sistem Pendukung Keputusan Pemilihan Karyawan Terbaik di PT. Fins Catering dengan Metode Simple Additive Weighting (SAW). Laporan diatas terdiri dari NIK, Nama Karyawan, Id Kriteria, Id Bobot, Loyalitas, Kehadiran, Kedisiplinan, Perilaku, Kinerja dan Hasil Akhir. Karyawan yang mendapat urutan satu merupakan karyawan terbaik yang berhak mendapatkan piagam penghargaan berupa uang dari PT. Fins Catering.

\section{SIMPULAN}

Berdasarkan hasil penelitian, maka ada beberapa yang dapat disimpulkan dalam Perancangan Sistem Pendukung Keputusan Karyawan Terbaik PT. Fins Catering, yaitu:

Sistem Pendukung Keputusan Pemilihan Karyawan Terbaik di PT. Fins Catering untuk Manager Operasional dapat membantu dan memberikan solusi bagi PT. Fins Catering. Untuk dapat menentukan karyawan terbaik yang berhak menjadi menerima hadiah sebagai bentuk apresiasi.

Dengan sistem ini PT. Fins Catering dapat menerapkan penilaian terhadap karyawan secara spesifik dan terdata.

\section{DAFTAR PUSTAKA}

[1] Ahmad, A., \& Kurniawan, Y. I. (2020). Sistem Pendukung Keputusan Pemilihan Pegawai Terbaik Menggunakan Simple Additive Weighting. Jurnal Teknik Informatika (Jutif), 1(2), 101-108. https://doi.org/10.20884/1.jutif.2020.1.2.14

[2] Fitriani, P., dan Alasi, T.S. 2020. Sistem Pendukung Keputusan dengan Metode WASPAS, COPRAS dan EDAS: Menentukan Judul Skripsi Mahasiswa. Yayasan Kita Menulis: Medan.

[3] Indrajani. (2015). Database Design. Jakarta: PT. Elex Media Komputindo.

[4] Kusrini. 2021. Konsep dan Aplikasi Sistem Pendukung Keputusan. Andi: Yogyakarta.

[5] Latif, L.A. dkk. 2016. Buku Ajar: Sistem Pendukung Keputusan Teori dan Implementasi. Deepublish: Yogyakarta.

[6] Limbong, T. dkk. 2020. Sistem Pendukung Keputusan: Metode dan Implementasi. Yayasan Kita Menulis: Medan.

[7] Lubis, A. 2016. Basis Data Dasar. Deepublish: Yogyakarta.

[8] Pareda, S., Mongi, C. E., \& Montolalu, C. E. J. C. (2019). Sistem Pendukung Keputusan Pemilihan Karyawan Teladan di PT Aneka Tambang (ANTAM) Tbk Unit Bisnis Pertambangan Buli Menggunakan Metode Simple Additive weight (SAW). D'CARTESIAN, 8(1), 1. https://doi.org/10.35799/dc.8.1.2019.22676 
JRKT (Jurnal Rekayasa Komputasi Terapan)

Vol 01 No 04 Tahun 2021

e-ISSN : 2776-5873

[9] Sukamto. dkk. 2014. Rekayasa Perangkat Lunak Terstruktur dan Berorientasi Objek. Bandung: Informatika Bandung.

[10] Tyoso, J.S.P. 2016. Sistem Informasi Manajemen Edisi Satu. Deepublish: Yogyakarta. 